\title{
Arkeolojik Cevre Bağlamında Yeni Yapı Tasarımı
}

\author{
Burkay PASİN ${ }^{\star}$ Güzden VARİNLİOĞLU**
}

Özet

Kültürel miras çok katmanlı yapısı sebebiyle arkeologlar için olduğu denli arkeolojik sit alanlarında tasarım yapan mimarlar için de karmaşık ve zorlayıcı bir bağlamsal veridir. Bu makalede öncelikle bağlam kavramının mimarlık disiplininde nasıl anlaşılıp yorumlandığı ve 1970’lerden itibaren mimarlık kuramcıları tarafından izlenen farklı bağlamsalcı yaklaşımlar irdelenmiştir. İkinci olarak arkeolojik çevre bağlamında mimarlık üretimi yaparken izlenebilecek tasarım yaklaşımları ve stratejileri üzerine odaklanılmıştır. Son olarak da, bir arkeolojik sit alanında yeni bir yapı tasarımının proje olarak verildiği bir mimari tasarım stüdyosunda alan çalışması uygulanmış, seçilen örnek projelerde öğrencilerin benzer ve farklı bağlamsal yaklaşımları karşılaştırmalı olarak analiz edilmiştir. Bu çalışmadan yola çıkarak, hem bu farklı yaklaşım ve stratejilerin mimari tasarım sürecinde nasıl kullanıldığını araştırmak hem de bu süreçte öznel verilerle nesnel sonuçlara da ulaşılabileceğini göstermek amaçlanmıştır.

Anahtar Sözcükler: kültürel miras, arkeolojik çevre, bağlam, bağlamsalcılık, mimari tasarım eğitimi

\section{New Building Design within the Context of Archeological Environment}

\section{Abstract}

Owing to its multi-layered structure, cultural heritage is a complex and challenging contextual datum not only for archeologists but also for architects who design at archeological sites. In this article, it is initially examined how the concept of context is understood and interpreted in the discipline of architecture as well as various contextual approaches followed by architectural theoreticians since the 1970s. Second, it is focused on possible design approaches and strategies to be followed while producing architecture within the context of archeological environment. Finally, a case study is applied to an architectural design studio where the students were asked to design a new building in an archeological site, and similar and different approaches of the students in selected projects are comparatively analyzed. Based on this study, it is both aimed to investigate how these different approaches and strategies are utilized during architectural design process and to show that objective results could be reached by subjective data in this process.

Keywords: cultural heritage, archeological environment, context, contextualism, architectural design education 


\section{Giriş}

Mimarlıkta bağlamsalcılık tarihsel süreç içinde birbiriyle kimi zaman örtüşen, kimi zaman da çelişen yaklaşımlar göstermiştir. 1950’li yıllardan itibaren modernist doktrinin yerel ve tarihsel bağlamı reddeden ilerlemeci tavrına karşıt olarak görsel bütünlük, tarihsel süreklilik, bölgeselcilik gibi bir mimari yapının dış çevresiyle ilişkilenmesi gerektiğini savunan farklı yaklaşımlar ortaya çıkmıştır. Daha güncel mimarlık söylemlerinde ise dış bağlam tartışmaları yerini her yapının bir iç bağlamı olduğunu savunan otonom mimarlık söylemine bırakmıştır.

Bir bağlamsal veri olarak kültürel miras kavramı karmaşık yapısı ile detaylı bir inceleme gerektirir. Özellikle çoklu katmanlara sahip bir kültür mirasının bulunduğu Türkiye'de ulusal ve uluslararası yasalar ölçüsünde gerçekleşen çeşitli uygulamalar olsa da daha çok yasaklayıcı bir koruma anlayışı vardır. Ancak Amerika ve İngiltere'de son yıllarda bir yöntem olarak arkeoloji disiplininin tahrip edici yaklaşımı yerini arkeolojik bulguyu yerinde korumayı (in-situ) öngören kültürel miras kavramına bırakmıştır. Artık arkeolojik bulgu bağlamından kopartılıp müzede sergilenen bir obje olmanın ötesinde yerinde korunan, sürdürülebilir, dolayısıyla gelecek nesillere aktarılabilen bir kültürel miras olarak görülmektedir. Bu dönüşen alanda bağlamsalcılık kavramına yeniden bakmak, bu makalenin kapsamını oluşturmaktadır.

Bir yapının hangi bağlamsal verilerle ne oranda ilişki kurması gerektiği, mimarlık uygulama ve söyleminin önemli tartışma konularından biridir. Mimari tasarım sürecinde görsel ve çevresel verilerle kurulan uyum ve karşıtlı ilişkileri daha doğrudan bir düşünsel çabayla çözümlenebilirken tarih, kimlik ve kültür gibi beşeri verilerle kurulan ilişkide daha dolaylı bir düşünsel süreç izlenmektedir. Böyle bir sürecin en özgün örneklerinden birini kültürel miras bağlamında görmekteyiz. Anadolu gibi zaman zaman ayrı tarihsel dönemlerin aynı lokasyonda üst üste yer aldığı bir coğrafyada kültürel mirası koruma ölçütleri de çok çeşitlidir ve bu bağlamda yeni bir yapı tasarlamak özenle irdelenip çözülmesi gereken bir sorunsaldır.

Bu makalenin hedefi kültürel miras gibi karmaşık bir olgunun mimari tasarım sürecinde bağlamsal bir veri olarak nasıl kullanıldığını ve mimari bir yapıda nasıl vücut bulduğunu araştırmaktır. Arkeolojik çevre bağlamında yeni yapı tasarımı tarihsel dokuya uyum, karşıtlık ve tümden reddetme gibi farklı tasarım modelleri izleyebilmektedir. Başka bir hedef ise bir arkeolojik çevrede tasarım yaparken öznel yoruma oldukça açık olan soyut beşeri verilerle nesnel sonuçlara da ulaşılabileceğinin gösterilmesidir. Bu hedefe ulaşabilmek için yöntem olarak bir arkeolojik sit alanında yeni bir yapı tasarımının proje olarak verildiği bir mimari tasarım stüdyosunda alan çalışması uygulanmış, seçilen örnek projelerde öğrencilerin benzer ve farklı bağlamsal yaklaşımları karşılaştırmalı olarak analiz edilmiştir. Dolayısıyla arkeolojik çevre bağlamında çalışmak mimari tasarım eğitiminde önemli bir öğrenim çıktısı olan karmaşık çevresel problemleri çözebilmek açısından da oldukça katkısı olan bir yaklaşım olarak kabul edilmektedir.

\section{Modern Mimarlıktan Günümüze Bağlamsalcılığın Kısa Tarihçesi}

Büyük Türkçe Sözlük'te “herhangi bir olguda olaylar, durumlar, ilişkiler örgüsü veya bağlantısı” olarak tanımlanan bağlam kavramı, mimarlık disiplininde çeşitli biçimlerde anlaşılıp yorumlanmıştır. Amerikalı mimar ve kuramcı Stan Allen (1997) bağlam yerine 'alan (field)' kavramının kullanmasını savunur. Carol Burns and Andrea Kahn (2005) da mimarlıkta bağlam yerine 'arazi (site)' kavramını kullanarak daha yere özgü bir ilişkisel kurguyu önermektedir. Benzer biçimde Amerikalı mimar ve kuramcı George Dodds (2001) da bağlam yerine bir arazinin kültürel ve geçici gerçekliklerini barındıran 'yenileme (instrauration)' kavramının önemini vurgulamaktadır. Bu makale kapsamında tartışılan bağlam kavramı yalnızca var olan yapı alanının topoğrafyası ve fiziksel koşulları değil, daha geniş kapsamda sosyo-kültürel, ekonomik, yasal, tarihsel ve yakın çevreye ilişkin tüm doğal, yapay ve öbür fiziksel koşullar olarak ele alınmaktadır.

Mimarlık üretiminde bağlam, doğrudan, dolaylı ya da örtük biçimlerde hep varlığını sürdürmekte olan bir olgudur. Özten ve Anay’a göre “'bağlamsalcı olmayan tasarım’ söylemi neredeyse bir oksimorondur; her mimari tasarım şu ya da bu biçimde bağlamsalcıdır” (Özten ve Anay, 2017:59). Benzer biçimde Erman ve Yılmaz'a göre “yapılar çevresinden bağımsız, bir boşlukta inşa edilemeyeceğine göre, mimari tasarım bir yere ilişkindir ve tasarımın ilişkin olduğu yerden kaynaklanan verilerle biçimlenmesi ya da yere özgü sorunlara karşılık vermesi beklenmektedir” (Erman ve Yılmaz, 2017:97).

Mimarlıkta bağlama ilişkin kuramsal yaklaşımlar ve tartışmalar ilk olarak 1950'lerin savaş sonrası döneminde Ortodoks modernist mimarlığın geçmişi ve geleneği reddeden ilerlemeci ve evrensel tasarım anlayışına tepki olarak doğmuş ve 
daha tutucu bir söylemsel çerçeve izlemiştir. Bu yaklaşımlar öncelikli olarak biçimsel ve biçemsel boyutlarda ele alınmıştır. 1949 yılında Architectural Review dergisi editörü Hubert De Cronin Hastings'in Ivor de Wolfe takma adıyla yazdığı makale 18. yüzyıl İngiliz Pitoresk kuramını İngiltere'deki savaş sonrası yapılaşmaya bir alternatif olarak öne sürer. Kentsel Peyzaj Hareketi olarak adlandırılan bu yaklaşım geçmiş örneklere bakarak bir peyzaj dağarcığı oluşturmak gerektiğini savunmaktadır (Wolfe, 1949).

Amerikalı mimar ve kuramcı Robert Venturi 1950 yılında Princeton Üniversitesi'nde savunduğu Mimari Kompozisyonda Bağlam adlı yüksek lisans tezinde Gestalt prensiplerinden yola çıkarak tarihsel yapıları analiz etmiş ve bağlamın mimari yapıya anlam kazandırdığı görüşünü ortaya koymuştur (Theunissen, 2010:53). Benzer biçimde İngiliz asıllı Amerikalı kuramcı Colin Rowe da Cornell Üniversitesi'ndeki kentsel tasarım yüksek lisans programında Gestalt prensiplerinden yararlanarak mimari araziyi "figür/zemin" bağlamında yorumlamış, "yapıların ideal tiplerin bir kolajı ya da brikolajı olarak kentsel bağlama göre düzenlenip çarpıtıldığı” bir tasarım anlayışını önermiştir. (Dağlığlu, 2015:274). Özten ve Anay’a göre Rowe'un kolaj ve brikolaj mantığı "bütünü belirsiz bir ilişkiler yumağı aracılığıyla örgütlemekte" ve "tasarımın belirsizlik, esneklik, kestirilemezlik, karmaşıklık yönüne vurgu yapmaktadır" (Özten ve Anay, 2017:63).

Bağlamsalcı yaklaşımın daha örgütlü bir örneği Temmuz 1953'te Congrès Internationaux d'Architecture Moderne (CIAM) kongresinde ortaya çıkmıştır. CIAM'ın barınma, çalışma, dolaşım ve rekreasyon gibi işlevleri ayrıştıran gridal bölgeleme anlayışını reddeden mimarlar Jaap Bakema, Georges Candilis, Giancarlo De Carlo, Aldo van Eyck, Alison Smithson, Peter Smithson ve Shadrach Woods, Team 10 (ya da Team X) adlı grubu kurarlar. Team 10'a göre bağlam “gündelik yaşamda ve var olan çevrede biçimlenen" sosyal bir olgudur (Dağlığlu, 2015:272). Hem modernist doktrinlere hem de İngiliz kentsel peyzaj hareketine eleştirel yaklaşan grup, biçimsel analoji ve tarihsel canlandırmacılık yerine ‘biçimsel birliktelik' ve ‘tarihsel süreklilik' gibi kavramları ön plana çıkarmıştır.

1980'li yıllara gelindiğinde eleştirel bağlamsalcı yaklaşımların düzeyi keskinleşmeye başlar. Venturi'nin postmodern söyleminde görsel iletişim araçları önemli bağlamsal referanslar durumuna gelirken buna karşıt olarak Eleştirel Bölgeselcilik (Critical Regionalism) gibi yerel dokuya uygunluğu gözeten yaklaşımlar da ortaya çıkmıştır. Norveçli mimarlık kuramcısı Christian Norberg-Schulz'un Genius Loci- Towards a Phenomenology of Architecture (1980) ve Kenneth Frampton'ın Towards a Critical Regionalism: Six Points for an Architecture of Resistance (1983) adlı çalışmalarında kuramsal temelleri atılan bu yaklaşım modernist söylemi tümden reddetmeden, mimarın bir bölgenin kendine özgü değişkenlerini eleştirel bir bilinçle yeniden yorumlamasını savunmaktadır. Norberg-Schulz'un (1980) “yerin ruhu” olarak tanımladığı, Frampton'un (1983) ise "tektonik ve çok algılı bir yaklaşım" olarak tartıştığı Eleştirel Bölgeselcilik, Alvar Aalto, Tadao Ando, Mario Botta, Charles Correa gibi mimarların doğal ışık, topoğrafya, tektonik ve malzeme kullanımlarında görülebilir.

Aynı yıllarda bağlamı bilinçli olarak reddeden kuramsal yaklaşımlar da görülmektedir. Amerikalı mimar ve kuramcı Peter Eisenman'ın Mimarlık ve Kentsel Çalışmalar Enstitüsü ve bu enstitünün süreli yayını Oppositions'da tartıştığı “otonomi paradigması" mimarlık üretiminde "dışsal etkenleri reddeden eleştirel bir yaklaşım” olarak ortaya çıkmıştır (Dağlığlu, 2015:267). Bu eleştirel yaklaşımı savunan Amerikalı mimarlık tarihçisi ve kuramcısı Kenneth Michael Hays'e göre mimarlık dışsal olan her şeyden kendini ayrıştıran bağımsız bir uygulamadır (Hays, 1984:22). Bağlamı reddeden bir başka yaklaşım da Rem Koolhaas'ın 'fuck context' söylemidir. 21. yüzyıl mimarlığında bir slogan durumuna gelen bu söyleme göre bir yapı belli bir büyüklüğe ulaştıktan sonra kendi iç bağlamını oluşturması nedeniyle bir dış bağlama gereksinim duymaz (Koolhaas ve Mau, 1993).

Modernizmden günümüze olan bu tarihçeyi özetlemek gerekirse mimarlık üretiminin bağlamla ilişkisi Venturi ve Rowe'un söylemlerinde yapılı çevreyi görsel bir referans olarak ele alarak dış etkenlere koşulsuz bağlanmıştır. Eisenman ve Hays'in otonom mimarlık iddiası ise bu etkenleri tamamen reddederek bir iç bağlam yaratma iddiasında bulunmuştur. Bu iki farklı söylemin arakesitinde hem modernist doktrinlere hem de tutucu tarihselciliğe belirli mesafede duran Team 10'in tarihsel süreklilik tezi ve Eleştirel Bölgeselcilik gibi söylem ve yaklaşımlar da 20. yüzyıl mimarlığının şekillenmesinde rol oynamıştır. Mimarlıkta bağlamsalcılığın ve bu makale özelinde arkeolojik çevreye olan katkısının daha iyi anlaşılabilmesi için kapsayıcı bir kavramsal çerçeveye ihtiyaç duyulmaktadır. 


\section{Kavramsal Çerçeve}

\section{Mimarlıkta Bağlamsalcı Yaklaşımlar}

Görüldüğü üzere mimarlıkta bağlamsalcı yaklaşımlar ya dış bağlamı biçimsel, yerel, iklimsel, tektonik boyutlarıyla ele almış ya da dış bağlamı tümüyle reddedip otonom bir iç bağlam arayışında olmuştur. Özten ve Anay bağlamsalcılı̆ga ilişkin kapsayıcı ve eleştirel okumalarında "hangi ölçekte çalışılırsa çalışıısın her mimari/kentsel tasarım probleminin kendi iç bağlamından ve onu çevreleyen dış bağlamlarından" yani "iç içe bağlamsal katman silsilesinden" söz etmenin olanaklı olduğunu belirtmektedir (Özten ve Anay, 2017:64).

Mimarlık kuramcısı David Smith Capon da bir yapının kendi içinde bir bütün olarak algılanabileceği gibi farklı yapıların kendi aralarında ve çevreleriyle olan ilişkisinin de önemli olduğunu vurgulamaktadır. Capon'a (1999) göre bu katmanları oluşturan bağlamsal veriler çok çeşitlidir ve üç başlık altında ele alınabilir: (1) Görsel Bağlam (boyut, ölçek, ritim, kütle, renk ve gereçler), (2) Çevresel Bağlam (iklimsel veri, bölgesel ve topografik özellikler), (3) Beşeri Bağlam (kimlik, kültür, tarih)

Bir mimari ürünün tasarım sürecinde bu veriler etkileşimli olarak ele alınabilir. Örneğin bir bölgenin iklimsel özellikleri yapının boyutlarına karar vermek için temel alınabilir ya da kullanılan malzemelere bölgenin tarih boyunca süregelen yapı üretim teknikleri ve kültürü referans alınarak karar verilebilir. Buna ek olarak bir mimari üründe görsel ve çevresel bağlamla kurulan ilişki daha nesnel, doğrudan algılanabilir ve kısa vadede deneyimlenebilir olmasına karşın tarihi ve kültürel miras gibi beşeri bir bağlamla kurulan ilişki daha öznel ve dolaylıdır; sürdürülebilir olması ve nesnelleşmesi için belirli bir zamana ve yaşanmışlığa gereksinim vardır.

\section{Kültürel Mirasa Mimari Yaklaşımlar}

UNESCO (2003) tarafından "her bir kültüre ve tüm insanlığa geçmişten aktarılan sanatsal ve sembolik ürünlerin bir toplamı" olarak tanımlanan kültürel miras, yalnızca somut nesneleri değil kimlik, hafıza, sözlü ve yazılı gelenek, ritüel gibi somut olmayan beşeri kavramları da barındırmaktadır. Ne var ki Uluslararası Müzeler Ofisi'nce Atina Tüzügüü’nün hazırlandığı 1931'den bu yana kültür mirasının korunması üzerine uluslararası konvansiyonlar maddi kültürün yerinde (in-situ) korunmasını desteklemek ve teşvik etmek ve yerinden kaldırılmasını kısıtlamak için ulusal ve uluslararası yasal çerçevelerin geliştirilmesini olanaklı kılmıştır. T.C. Kültür ve Turizm
Bakanlığı'nca 17.08.1988 günü duyurulmuş Kültür ve Tabiat Varlıklarını Koruma Kanunu'nda listelenmiş alanlarda arkeolojik sit alanlarına el atmaları kısıtlamaktadır. Benzer şekilde, Amerika Ulusal Parklar Servisi'nin Arkeoloji ve Tarihi Koruma Standartları Kılavuzu'na göre kültürel mimari mirasa dört farklı şekilde yaklaşılabilir: koruma, iyileştirme, restorasyon ve rekonstrüksiyon (Weeks ve Grimmer, 1995). Bu çerçeveler kültürel mirasın korunması için öngörülen yaklaşımlar olduğ denli bu mirasa yakın yerlerde tasarlanacak yeni yapılar için de bağlamsal ipuçları sunmaktadır.

Yerel ve çevresel bağlamın görece daha uygulanabilir ve sürdürülebilir ortamıyla karşılaştıııldığında kültürel miras hem arkeologlar hem de bu bağlamda tasarım yapan mimarlar için sorunlu bir alandır. Arkeoloji sistematik bir veri toplama yöntemidir ve arkeolojik yüzey araştırmaları ve kazılarda geleneksel veri toplamada el atmacı yöntemler kullanılagelmiştir. Arkeoloji uygulamalarında geçmiş üzerine bilgi edinmek üzere izlenen araştırma, kazı, veri çözümlemesi ve yorumlama yöntemler geçmişin gerçekliğini belli oranda bozmakta ve edinilen bulguları bağlamından kopartarak kayıt altına alınan birer araştırma nesnesine indirgemektedir (Sprinkle ve John, 2003:253). Bu uygulamalarda taşınabilir kültürel miras taşınamaz olandan kopartılıp müzelerde sergi objesi haline getirilir ve böylece bağlamsal bütünlük bozulur. Buna ek olarak, taşınamaz olan yapı kalıntıları da var olduğu çevresel dokuya hem fiziksel hem de sosyal olarak yabancı duruma gelir. Böyle bir ortamda yönetmeliklerin el verdiği ölçüde yeni bir mimarlık ürünü ortaya çıkarmak sınırlayıcı olduğu denli duyarlı bir tasarım yaklaşımı gerektirmektedir. Ancak ölçülü ve tutarlı çözümler bulunması durumunda hem mimarlık uygulaması hem de mimarlık eğitimi ortamında kültürel miras bağlamında mimarlık yapmak oldukça öğretici bir süreçtir.

\section{Arkeolojik Çevre Bağlamında Mimari Örneklem}

Amerikalı mimarlık kuramcısı Linda Groat, tarihsel çevrede bir yapının bağlamıyla ilişkisini belirlerken mimarın kullanabileceği bir uygulama çerçevesi önermektedir. Bu çerçeveye göre mimarın üzerinde en çok söz sahibi olduğu parametreler yapının dışında 'arazi organizasyonu, hacim ve yüzey kompozisyonu', yapının içinde ise 'mekân organizasyonu, dekorasyon ve yüzey kompozisyonudur' (Groat, 1983).

Amerikalı yapı restorasyon uzmanı Michael Davies ise tarihsel bir çevrede tasarım yaparken beş farklı yaklaşımın olduğu bir model önermektedir: 
(1) Öykünme Yaklaşımı: Bir yapının yakın çevresindeki tarihsel dokuya yüzeysel ve düzensel olarak öykünmesine dayalı yaklaşım

(2) Gelenekselci Yaklaşım: Tarihsel dokunun biçim, malzeme ve ayrıntılarını yeni yapıya uyarlama yaklaşımı

(3) Kibirli Yaklaşım: Tarihsel dokuyu tümüyle yok sayan bencil ve riskli bir yaklaşım

(4) Güncel Yaklaşım: Tarihsel dokudan esinlenip saygı gösteren güncel tasarım yaklaşımı

(5) Üstü Kapalı Yaklaşım: Tarihsel dokuya alçakgönüllü ve çekingen bir ölçüde dokunan korumacı yaklaşım

2007 yılında yayımlanan Büyük Philadelphia Koruma Antlaşması'nda tarihsel bölgelerde yeni yapılaşmalar için Davies'in modeline benzer dört farklı tasarım stratejisi öngörülmüştür:

(1) Aslına Uygun Kopyalama: Davies'in öykünme yaklaşımına benzer olan bu stratejide yapılı çevreye olabildiğince öykünülür ve yeni ile eski çevre arasındaki farklılıklar en aza indirgenir.

(2) Bir Üslup İçinde Keşif: Yapılı çevreye öykünmeden ve tasarım dilindeki tutarlılığı koruyarak tasarım yapılır.

(3) Soyut Referans: Soyut bir tasarım dili kullanılarak tarihsel çevreyle yeni yapı arasında öykünmeden uzak bir iletişim kurulur.

(4) Kasıtlı Karşıtlık: Bağlamsal bütünlüğü karşıtlıkla sağlamaya çalışan bir yaklaşımdır.

$\mathrm{Bu}$ model ve stratejiler içinde uygulama açısından en hassas düşünülmesi gerekenler öykünme yaklaşımı ve aslına uygun kopyalamadır. Çünkü ne denli dikkatli uygulanırsa uygulansın, bir tarihsel dokunun yüzeysel özelliklerine öykünmek, kültürel mirasın gelecek kuşaklara aktarılırken hiçbir bağlama tümüyle uymayan ve sürdürülebilirliği kuşkulu bir mimari nesneye indirgenmesine neden olabilir.

Arkeolojik çevrenin doğrudan referans alındığı yapı tipleri çoğunlukla arkeolojik sit alanlarına yakın konumlandırılmış müze ve ziyaretçi merkezi gibi yapı tipleridir. Bu alanlarda yapı tasarlayan mimarlar yukarıdaki yaklaşım ve stratejilerden bir ya da birkaçını izleyebilir. Örneğin Bernard Tschumi Parthenon tapınağının güneydoğusundaki tarihsel Makryianni bölgesinde tasarladığı Yeni Akropolis Müzesi'nde tapınağa so- yut referanslar vererek güncel bir bağlamsal yaklaşım izlemiştir. Zemin katından temeldeki kazı alanının izlenebildiği yalın bir geometrisi olan müzenin Parthenon Galerisi adı verilen üçüncü katında tapınağın orijinal plan şeması kullanıımış ve zemin katta kolon aksları aynı orantıda yeni teknoloji ve malzemelerle yeniden yorumlanmıştır.

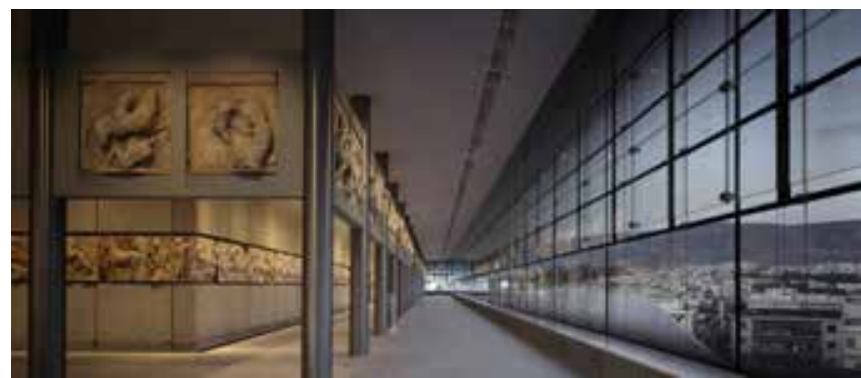

Resim 1. Atina Yeni Arkeoloji Müzesi içten görünüm (https:// www.archdaily.com/61898/new-acropolis-museum-bernardtschumi-architects/500918b128ba0d27a70017a9-newacropolis-museum-bernard-tschumi-architects-image)

2014 yılında yapılan ve 'kitsch' denebilecek Üsküp Arkeoloji Müzesi, Makedonya'nın klasik Roma ve Osmanlı mimarlık kültürünü neoklasik bir biçemle cephe kompozisyonunda yüzeysel ve düzensel temelde yansıtmakta, dolayısıyla öykünme yaklaşımı ve aslına uygun kopyalamaya örnek oluşturmaktadır.

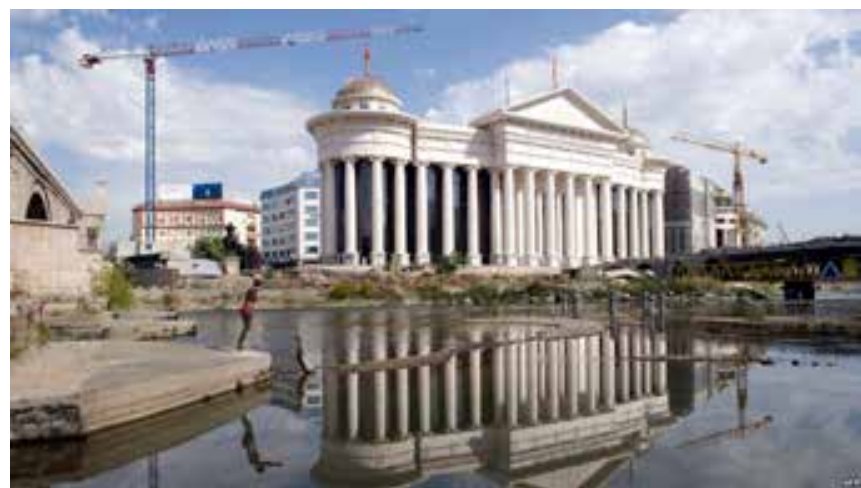

Resim 2. Üsküp Arkeoloji Müzesi genel görünüm (https://www. rferl.org/a/skopje-kitsch-renewal-statues/25187521.html)

Çek mimar Radko Kvet tarafından 2016 yılında Çek Cumhuriyeti'nin Pavlov şehrinde arkeolojik bir sit alanı içinde tasarlanan Archeopark Müzesi bölgede antik dönemde yaşayan avcı topluluğu ve kültürüne ait buluntuların sergilendiği bir yapıdır. Antik dönemdeki mağara yerleşimlerine referansla ana bloğu yerin beş metre altına gömerek oluşturulan yapı- 
da yer üstünde yükselen beyaz betonarme kuleler hem yeraltına ışık almak hem de çevresel bağlama simgesel bir katkıda bulunmak üzere tasarlanmıştır. Dolayısıyla güncel bir yaklaşımın izlendiği yapıda, yer altındaki yapı bloğu antik yaşam formlarına soyut bir referans verirken, yer üstündeki kuleler bu biçem içindeki yeni bir keşif olarak değerlendirilebilir.



Resim 3. Pavlov Arkeoloji Müzesi genel görünüm (https://www. archdaily.com/795684/archeopark-pavlov-kvet-architects)

Bu örneklerde de görüldüğüu üzere, kültürel miras beşeri bağlam katmanının bir parçası olsa da, görsel ve çevresel bağlamla da çok yakın ilişki içindedir ve bu alandaki en belirleyici referanslar mimari tipoloji, tarihsel katman, yapı teknolojisi, malzeme kullanımı, topoğrafyaya uyum gibi özelliklerdir. Ancak görsel ve çevresel bağlamla olan ilişki, verinin doğası gereği daha nesnel olabilirken, mimari tipoloji ve tarihsel sürdürülebilirlik daha yoruma açık ve öznel referanslardır.

Bu mimarlık uygulamalarına ek olarak son birkaç yıldır birçok mimarlık okulunda arkeolojik çevrede tasarım kültürel mirasa olan sorumluluk bilinciyle mimarlık eğitiminin bir parçası haline gelmeye başlamıştır. İspanya'daki Valladolid Üniversitesi, Portekiz'deki Porto Üniversitesi ve İtalya'daki Roma Tre Üniversitesi ortaklığında bir Avrupa Birliği projesi olarak yürütülen 'Mimarlı, Arkeoloji ve Peyzaj' projesi buna örnektir (Carvalho vd. 2013). Bir başka örnek de mimarlık eğitiminde kültürel mirasın korunmasında izlenebilecek çağdaş yaklaşımları ortaya çıkarmak üzere Belgrad Üniversitesi Mimarlık Fakültesi'nde 2009 yılına kadar Naissus ve Timacum Minus antik şehirlerinde yaptırılan öğrenci projeleri dizisidir (Roter-Blagojević, Milošević ve Radivojević, 2009).

\section{Yöntem}

Hem kültürel mirasa yönelik farkındalığı arttırmak hem de arkeolojik çevrenin oluşturduğu bağlamın tasarım sürecine etkisini ve katkısını ölçmek amacıyla İzmir Ekonomi üniversitesi ikinci sınıf mimari tasarım stüdyosunun final projesinde her bahar döneminde arkeolojik bir sit alanında çalışılmaktadır. İkinci sınıf seviyesinde form, strüktür, fonksiyon ve mekân arasındaki çoklu ilişkileri keşfederken öğrencilerin hangi bağlamsal katmanları referans aldıkları, nasıl bir tasarım yaklaşımı ve stratejisi izledikleri tasarım eğitimi pedagojisi açısından oldukça önemlidir.

Bu makalede yöntem olarak söz konusu stüdyoda bir alan çalışması uygulanmıştır. Çalışma kapsamında teslim edilen 96 proje arasından proje alanını görece daha iyi kavrayan ve kültürel mirasla olan ilişkilerinde ön plana çıkan en başarılı 6 proje seçilmiştir. Bu projelerden her biri saha gezisindeki analiz çalışmalarından son proje etütlerine kadar olan süreçte en az bir bağlamsal veriye (görsel, çevresel, beşeri) referans vererek birbiriyle benzeşen ya da farklılaşan bağlamsal yaklaşımlar (öykünme, gelenekselci, kibirli, güncel, üstü kapalı) ve stratejiler (aslına uygun kopyalama, bir üslup içerisinde keşif, soyut referans, kasıtlı karşıtlık) izlemişlerdir. Daha sonra bu veri, yaklaşım ve stratejilerin karşılaştırmalı bir analizi ve değerlendirilmesi yapılmıştır.

\section{Alan Çalışması}

\section{Arazi ve Bağlam}

2016-2017 Bahar Dönemi'nde ARCH 202 Mimari Tasarım Stüdyosu'nda verilen 'Yassıtepe Archeopark: Dijital bir Arkeolojik Araştırma ve Ziyaretçi Merkezi’ projesi alan çalışması olarak seçilmiştir. Proje kapsamında öğrencilerden, arkeologlar, arkeoloji öğrencileri, araştırmacılar ve sıradan ziyaretçilerin kullanımına açık çok amaçlı bir salon ile araştırma, sergi, konaklama ve yönetim birimlerinden oluşan yaklaşık 1500 metrekarelik kapalı alana sahip bir yapı kompleksi tasarlamaları istenmiştir. Buna ek olarak yapılaşmaya uygun sınırlar içinde Yassıtepe arkeolojik kazı alanıyla fiziksel ve/veya soyut bir çeşit ilişki kurmaları ve buna uygun bir ziyaret ve dolaşım senaryosu oluşturmaları beklenmiştir.

Proje arazisi İzmir'in Bornova İlçesi Kazım Dirik Mahallesi sınırları içinde yer alan kuzeyde Yassıtepe Höyüğü ve Forum Bornova Alışveriş Merkezi, batıda İzmir-Çanakkale otobanı ve güneyde Yeşilova Höyüğü, Manda Çayı ve müstakil villalar ile çevrili 12.800 metrekarelik $\mathrm{L}$ şeklinde bir parseldir. 


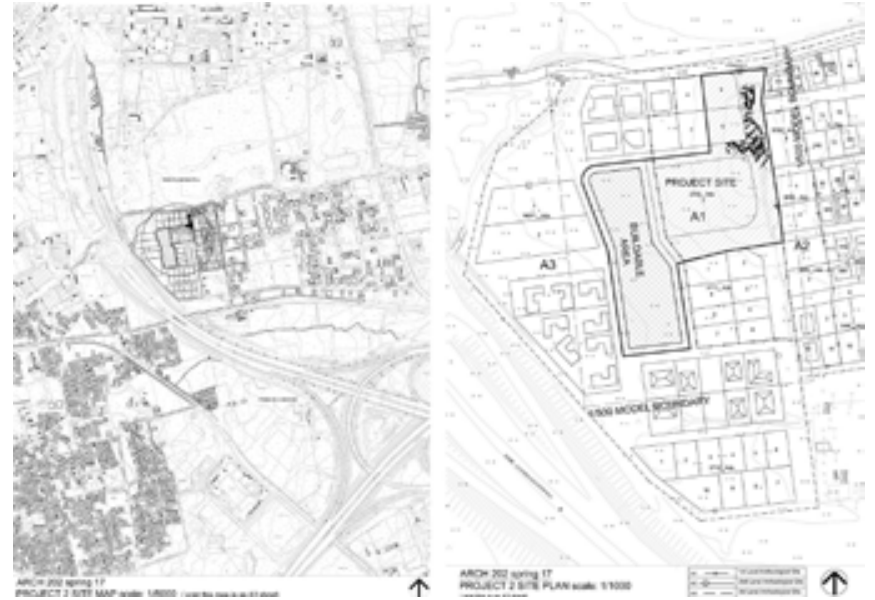

Resim 4. Solda: Kazım Dirik Mahallesi ve çevresini gösteren 1/5000 ölçekli harita (Kaynak: Bornova Belediyesi Dijital Arşivi), Sağda: Yassıtepe Archeopark proje arazisi 1/1000 ölçekli yerleşim planı (Çizim: Burkay Pasin)

Yassıtepe Höyüğü, İzmir kent kültürünün ortaya çıktığı Bornova Ovası üzerinde yer alan, günümüze ulaşabilmiş prehistorik höyüklerden biridir. Höyük yüzeyinde ve açılan çukurlarda bulunan çanak çömlek parçaları, höyükte en az dört kültür katmanının olduğunu göstermektedir: Geç Neolitik Çağ, Kalkolitik Dönem, Tunç Çağı, Erken Bizans Dönemi. Höyük kuzey güney doğrultusunda yaklaşık 400 m., doğu-batı doğrultusunda $300 \mathrm{~m}$. boyutlarındadır. Denizden yüksekliği $20 \mathrm{~m}$. dolaylarında olan tepede 5-6 m. yüksekliğinde kültür dolgusunun olduğu düşünülmektedir (Derin, 2006:2-3). Araştırma ekibi tarafından açılan iki metre derinliğindeki çukurun tabanında mimari yerleşimlere ait kuzeydoğu-güneybatı ekseninde örülmüş taş duvar kalıntıları ve gömütler yer almaktadır. Höyükte Neolitik dönemden başlayarak biçimlenen kültürlerin İzmir kent tarihinin yanı sıra Ege Bölgesi'nin kültür tarihinin ortaya çıkmasında da etkili olduğu düşünülmektedir.

Projenin başlangıç aşamasında Yassıtepe Arkeolojik kazı alanına ve höyügün güneydoğusunda yer alan, yine aynı kazı ekibince çalışılmış Yeşilova Höyüğü’ne bir araştırma ve inceleme gezisi gerçekleştirilmiştir. Özellikle Yeşilova Höyüğü yakınında Evren Başbuğ ile Umut Başbuğ tarafından 2010 yılında tasarlanan yeni ziyaretçi merkezi yapısı arkeolojik bağlamda yeni yapı tasarımına iyi bir örnek oluşturması bakımından oldukça iyi bir referans olmuştur. Kazı başkanı arkeolog Dr. Öğr. Üyesi Zafer Derin kılavuzluğunda yapılan gezi kapsamında öğrenciler eskiz, fotoğraflama, yerinde ölçüm yöntemleriyle hem bölgenin çok katmanlı arkeolojik yapısını hem de kendi proje arazilerinin arkeolojik kalıntılarla olan doğrudan ve dolaylı ilişkilerini analiz etme olanağı bulmuşlardır.

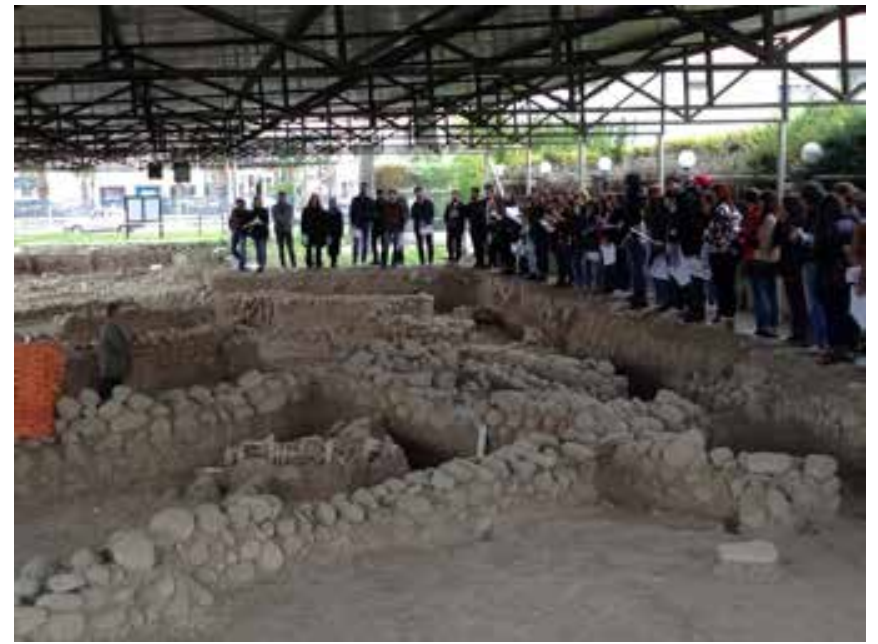

Resim 5. Yassıtepe Höyüğü arazi gezisinden görünüş. Fotoğraf: Burkay Pasin

\section{Karşılaştırmalı Analiz}

Tablo 1'de görüldüğü üzere seçilen bütün projeler arkeolojik kalıntılarda gözlenen mimari tipolojiyi beşeri bir bağlamsal veri olarak göz önüne almış, bunun dışında yapı teknolojisi, görsel geçirgenlik, tarihsel katman, ölçek ve malzeme kullanımı gibi verilerden de bir ölçüde yararlanmışlardır. İzledikleri bağlamsal yaklaşımlar (güncel, gelenekselci, üstü kapalı, biçem içinde keşif) ve stratejiler (soyut referans, kasıtlı karşıtlık, aslına uygun replikasyon) kendi içinde değişiklik göstermekte olup, bir öğrencinin birden fazla yaklaşıma sahip olabildiği de görülmektedir.

Tablo 1: Alan çalışması için seçilen öğrencilerin proje sürecinde bağlamla ilişkileri

\begin{tabular}{|c|c|c|c|}
\hline Öğrenei & Bağlamsal Veri & Bağlamsal Yaklaşım & Bağlamsal Strateji \\
\hline EK & $\begin{array}{l}\text { mimari tipoloji } \\
\text { tarihsel katman }\end{array}$ & gûncel & soyut referans \\
\hline ECK & $\begin{array}{l}\text { mimari tipoloji } \\
\text { görsel geçirgenlik }\end{array}$ & gûncel & kasıth kaŗ̧thk \\
\hline ISK & $\begin{array}{l}\text { mimari tipoloji } \\
\text { yape teknolojisi } \\
\text { görsel gecirgenlik }\end{array}$ & $\begin{array}{l}\text { gûncel } \\
\text { ũstü kapahı }\end{array}$ & kasıth karşathk \\
\hline ONU & $\begin{array}{l}\text { mimari tipoloji } \\
\text { yapı teknolojisi } \\
\text { malzeme kullanums }\end{array}$ & $\begin{array}{l}\text { gelenekselei } \\
\text { ûslup içinde keşif }\end{array}$ & soyut referans \\
\hline$\$ \mathrm{~A}$ & $\begin{array}{l}\text { mimari tipoloji } \\
\text { ölçek }\end{array}$ & $\begin{array}{l}\text { ôykünme } \\
\text { gelenekselei }\end{array}$ & aslina uygun replikasyon \\
\hline SK & $\begin{array}{l}\text { mimari tipoloji } \\
\text { yapu teknolojisi }\end{array}$ & gûncel & kasıth karşthk \\
\hline
\end{tabular}

Mimari tipoloji kullanımında Yassıtepe Höyüğü kalıntılarının 
kuzeydoğu-güneybatı yönünde diyagonal yerleşen parçalı kütle şeması temel referans olarak alınmıştır. Ancak kimi projeler bu şemayı güncel bir yaklaşımla yeniden yorumlarken (EK, ECK, SK), kimileri gelenekselci bir yaklaşımla kendi proje şemalarına uyarlamışlardır (ÜNU, ŞA). Örneğin, EK'nın projesinde parçalı kütle yaklaşımı höyüğün diyagonal yerleşimine soyut bir referansla sergi alanlarını höyükte bulunan dört tarihsel katmana göre düzenlemeyi öngörürken, SK'nın projesinde höyüğün yerleşim eksenine karşıt dolaşım eksenleri üzerine mekânlar parçalı olarak yerleştirilip kapalı tek bir hacim içine alınarak bir karşıtlık sergilenmiştir.
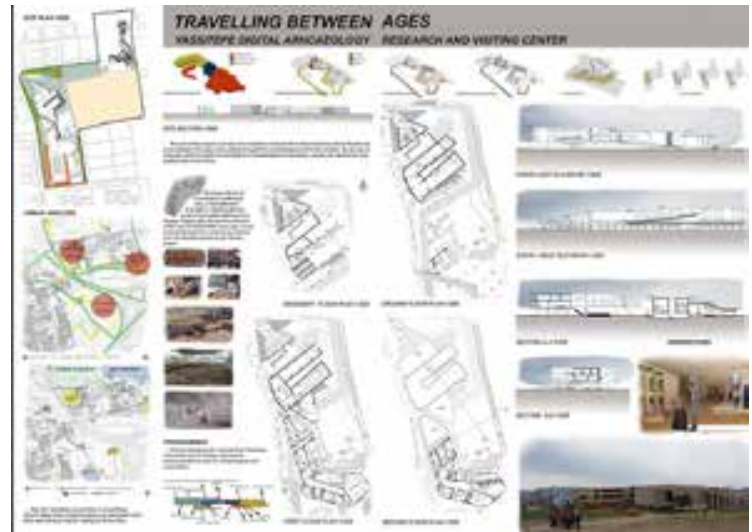

Resim 6. EK’nın Proje Sunum Paftası (IEU Mimarlık Dijital Arşivi)

Benzer biçimde, ECK'nın projesi de farklı kamusallıktaki mekân gruplarını kentin farklı noktalarına referans veren eksenler üzerinde düzenleyen bir karşıtlık öngörmektedir. İzledikleri bu kasıtlı karşıtlık stratejine karşın tarihsel dokuya saygılı güncel yaklaşımları, ECK'nın projesinde arkeolojik alanı gören cephelerde kullandığı görsel geçirgenlikle, SK'nin projesinde ise höyükteki yığma duvarları farklı bir ölçekte yeniden yorumlayan kaset döşemeler ve sağır duvarlardan oluşan betonarme yapı teknolojisiyle sağlanmıştır. Bu öğrencilerden hiçbiri arkeolojik kazı alanıyla fiziksel bir bağlantı kurmamıştır.

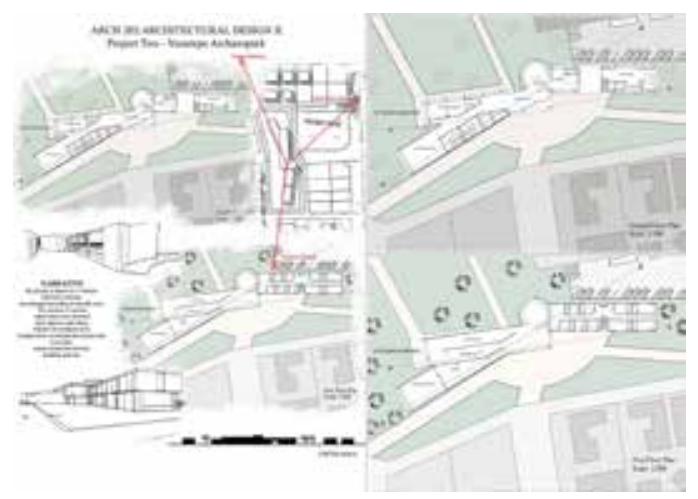

Resim 7. ECK’nın Proje Sunum Paftası (IEU Mimarlık Dijital Arşivi)

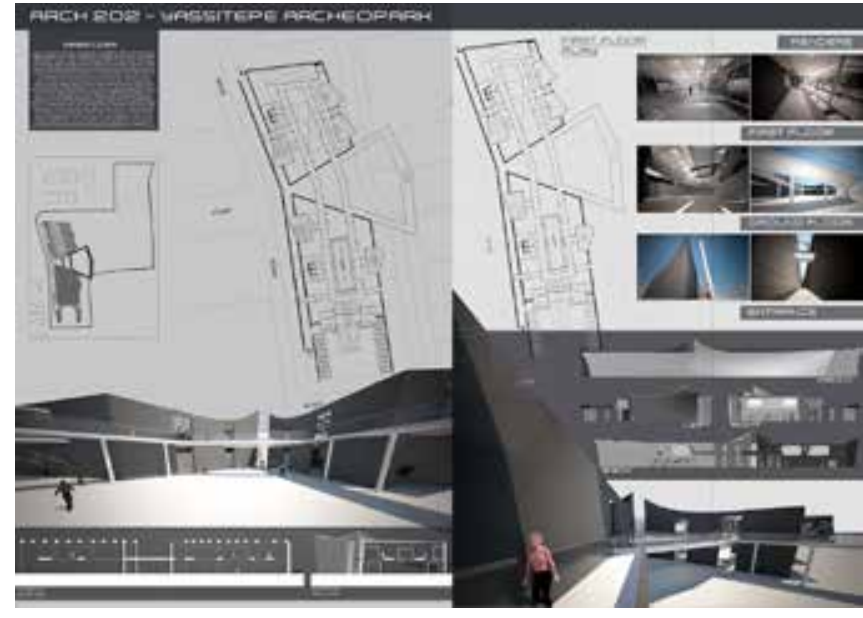

Resim 8. SK'nın Proje Sunum Paftası (IEU Mimarlık Dijital Arşivi)

Gelenekselci yaklaşımı izleyen iki proje (ÜNU, ŞA) höyüğün parçalı yerleşim yapısını yeniden yorumlarken farklı stratejiler izlemişlerdir. üNu, höyükteki kalıntı yığma duvarları kendi projesinde farklı bir duvar örgü sistemine dönüştürerek soyut bir referansla yeniden yorumlamış, dolayısıyla antik mimari biçem içinde yeni bir mimari keşif gerçekleştirmiştir. üNU'nun projesinde duvarlar hem aynı kalıntılarda olduğu gibi yapı kompleksi için taşıyıcı işlev görmekte, hem de yapının çeperlerinde ikinci bir cidar oluşturarak yarı kamusal bir dolaşım alanı yaratmaktadır.
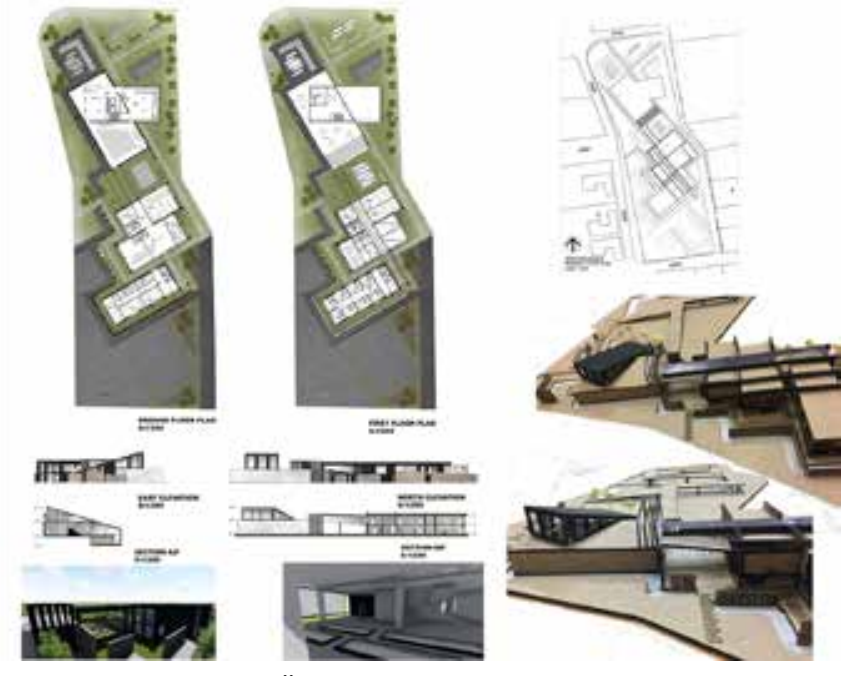

Resim 9. ÜNU'nun Proje Sunum Paftası

ŞA ise aynı duvarları ve bu duvarların yerleşimlerini aynı ölçekte yüzeysel biçimde ve aslına uygun yaparak bir öykünme yaklaşımı sergilemiştir. ŞA'nın plan şemasına bakıldığında prehistorik dönemdeki bitişik düzen ve parçalı konut yerle- 
şiminin mekânların işlevlerine bakılmaksızın araştırma, sergi ve konaklama birimlerinde modüler olarak yinelendiği görülmektedir. Bu iki öğrenci de kazı alanıyla fiziksel bir bağlantı kurmamışlardır.

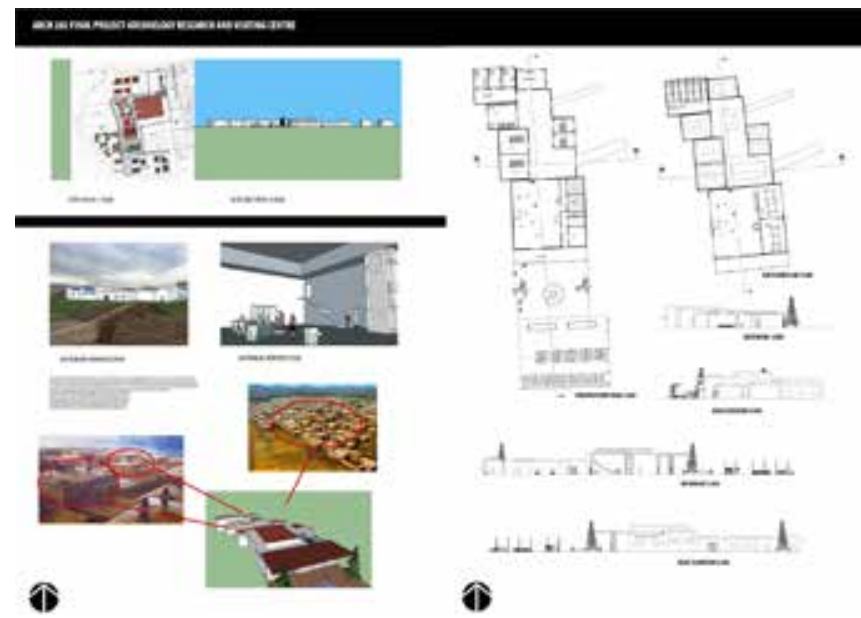

Resim 10. ŞA'nın Proje Sunum Paftası (IEU Mimarlık Dijital Arşivi)

Projeler içinde üstü kapalı yaklaşımı izleyen tek öğrenci ISK, arkeolojik dokuya en az referans vermiş, ancak görsel geçirgenliği sağlamak üzere yararlandığı betonarme ve giydirme cephe yapı teknolojisi ve içe dönük sağır kütle şeması ile aynı zamanda kasıtlı bir karşıtlık yaratmıştır. ISK, yapı kompleksi tasarımındaki bu çekingen üstü kapalı yaklaşımına karşıt olarak arkeolojik kazı alanıyla su öğesi ve köprülerden oluşan ve ziyaretçilerin dolaşım senaryosuna uygun bir peyzaj düzenlemesiyle fiziksel bir bağlantı kurmuştur.
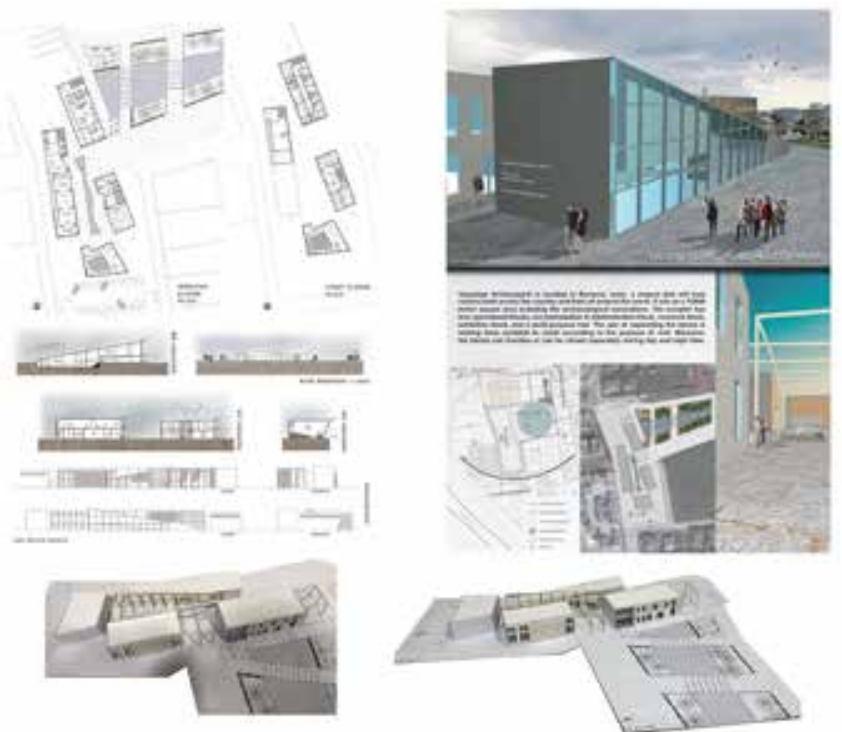

Resim 11. ISK’nın Proje Sunum Paftası (IEU Mimarlık Dijital Arşivi)
Bu analizde görüldüğü üzere kültürel miras bağlamında mimarlık üretirken gerek güncel gerekse gelenekselci yaklaşımlarda izlenen stratejiler değişebilmekte, bu da öğrencilerin tasarım sürecine çeşitlilik getirmekte ve özdeş bağlamsal verileri kullanırken tekdüze bir düşünce kalıbında kalmalarının önüne geçmektedir. Böyle bir kalıbın belki de tek örneği gelenekselci bir öykünme yaklaşımında aslına uygun replikasyon stratejisi kullanan ŞA adlı öğrencinin projesidir. Ancak bu projede bile öykünülen ölçek, doku ve gereç, projenin gerektirdiği program içinde bir ölçüde yeniden biçimlenmiştir. Bu da kültürel mirasın çok katmanlı yapısı içinde tarihsel dokuya hiçbir zaman aslına tam anlamıla uygun öykünülemeyeceğinin, her zaman bir ölçüde yeniden yoruma gereksinim duyulduğunun göstergesidir.

$\mathrm{Bu}$ analizden edinilen başka bir bulgu ise öğrencilerin kültürel mirası yorumlarken gösterdikleri öznel yaklaşımların sürdürülebildiği ölçüde nesnel çözümlere olanak verme potansiyelinin olmasıdır. Örneğin EK ve SK'nın Yassıtepe Höyüğü'ne referans veren dolaşım şemaları, arkeolojik sit alanlarında yapılabilecek benzer kamusal yapılar için bir model önerisi getirmektedir. ÜNU ve ŞA'nın höyükteki duvar örme tekniklerini yeniden yorumlama biçimleri de benzer şekilde bir yapı üretim tekniğinin sürdürülebilir bir kültürel norm, hatta yasal çerçevede bir koruma ölçütü olarak benimsenmesi için bir model oluşturmaktadır.

\section{Sonuç}

Arkeolojik çevre bağlamında farklı yaklaşım ve stratejilerin mimari tasarım sürecini nasıl etkilediğinin araştırıldığı bu makalede bir mimari tasarım stüdyosu deneyimi üzerinden bu yaklaşım ve stratejilerin uygulanması karşılaştırmalı olarak analiz edilmiştir. Özellikle tarihsel dokudaki mimari tipoloji analiz edilen her projede yeğlenmesine karşın, izlenen bağlamsal yaklaşım ve stratejiler farklılık göstermektedir. Bu da kültürel miras gibi hem somut ürünler hem de soyut kavramları niteleyen karmaşık bir olgunun tek tip, yüzeysel ve indirgemeci bir yaklaşımla ele alınamayacağının bir göstergesidir.

$\mathrm{Bu}$ alan çalışmasında analiz edilen projelerin kültürel mirasa yaklaşımı makalenin kuramsal çerçevesini destekler niteliktedir. Hemen her projede öğrenciler arkeolojik çevredeki bir dış bağlama referans verirken yorumlama, soyutlama ve karşıtlık gibi yöntemlerle örtük olarak bir iç bağlam da yaratmışlardır. Dolayısıyla Özten ve Anay’ın sözünü ettiği iç ve dış 
bağlam silsilesine maruz kalmak arkeolojik çevrede mimarlık üretirken karşılaşılan kaçınılmaz bir durumdur.

$\mathrm{Bu}$ makale yalnızca kültürel miras bağlamında mimari tasarım yapmanın çok katmanlı karmaşıklığını göstermekle kalmamış, aynı zamanda mimarlık eğitiminde bu tarz çok boyutlu ve karmaşık problemlere yaklaşırken nasıl bir yol izlenmesi gerektiği konusunda da ipuçları vermiştir. Bu anlamda ikinci sınıf düzeyinde karmaşık mimari problemlerin çözülmesini ve tarihsel yapılı çevreye farkındalık gösterilmesini hedefleyen bir tasarım stüdyosunun öğrenim çıktılarını da karşılamış olmaktadır. Böylelikle mimari tasarım eğitiminde bağlamın tasarım sürecine etkisi ve katkısı, ülkemizde keskin hatlarla tanımlanmış arkeolojik çevresel bağlam aracılığıyla aktarılmıştır. Mevcut bağlama yeni yaklaşımların örneklendiği bu çalışma ile sadece öğrencilerin yaklaşımları değil, dolaylı olarak arkeolojik bağlamda yeni yapı tasarımı kategorileri de tartışılmıştır.

\section{Kaynakça}

Allen, S. (1997). "From Object to Field, AD Profile 127", Architectural Design, Sayı 67, no. 5/6, s. 24-31.

Burns, C. J. ve Kahn, A. (2005). "Why Site Matters" (Ed.: C. J. Burns ve A Kahn), Site Matters: Design Concepts, Histories, and Strategies, New York: Routledge, $\mathrm{xv}$

Büyük Türkçe Sözlük, Türk Dil Kurumu, http://www.tdk.gov. tr/index.php?option=com_bts\&arama=kelime\&guid=TDK. GTS.5aaa3399504a71.29471742 (15.03.2018)

Capon, D. S. (1999). Architectural Theory - Volume 2: Le Corbusier`s Legacy, John Wiley \& Sons.

Carvalho, M., Fernández, S., Pujiac, L., Rocha C., Rodríguez, C., Zelli, F. (2013). "Architecture, archaeology and landscape, an interdisciplinary educational experience in archaeological sites”, Procedia Chemistry, Sayı 8, s. 292-301.

Dağlıoğlu, E. K. (2015). "The Context Debate: An Archaeology", Architectural Theory Review, Sayı 20(2), s. 266-279.

Davies, M., Design in the Historic Environment, http:// www.buildingconservation.com/articles/design/design.htm (24.02.2018)

Derin, Z. (2006). “İzmir’den İki Yeni Prehistorik Yerleşim Yeri: Yassıtepe Höyüğü, Çakallar Tepesi Höyüğü̈, Arkeoloji Dergisi, Sayı VII (2006/1).

Dodds, G. (2001). "Architecture as Instauration", Architectural Research Quarterly, Sayı 5(2), s. 126-150.
Erman, 0. ve Yılmaz, N. (2017). "Mimari Tasarımda Konsept ve Bağlam İlişsisi Üzerine”, Uluslararası Hakemli Tasarım ve Mimarlık Dergisi, Sayı 10, Kış - İlkbahar, s. 97-115.

Frampton, K. (1983). "Towards a Critical Regionalism: Six Points for an Architecture of Resistance", Editör: H. Foster, The AntiAesthetic - Essays on Postmodern Culture, Seattle: Bay Press, s. $16-30$.

Groat, L. (1983). "Measuring the fit of new to old: A checklist resulting from a study of contextualism". Architecture: The AIA Journal, Sayı 72 (11), s. 58-61.

Hays, K. M. (1984). "Critical Architecture: Between Culture and Form”, Perspecta, Sayı 21, s. 14-29.

Koolhaas, R. ve Mau, B. (1993). Bigness or the Problem of Large, $S M L X L: O M A$.

Norberg-Schulz, C. (1980). Genius Loci, Towards a Phenomenology of Architecture, New York: Rizzoli.

Özten, Ü. ve Anay, H. (2017). “Bağlamsalcılığın İki Yüzü: Tepeleri ve Vadileri Pahlanmış Bir Dünyada Bağlamsalcılık Hususuna Yeniden Bir Bakış”, Megaron, Sayı 12(1), s. 57-66.

Roter-Blagojević, M., Milošević, G., Radivojević, A. (2009). A new approach to renewal and presentation of an archaeological site as unique cultural landscape, SPATIUM International Review, Sayı 20, s. 35-40.

Sprinkle, Jr., John H. (2003). "Uncertain Destiny, the Changing Role of Archeology in Historic Preservation", Editorler: E. Robert, ve S. A Richer, Heritage: Historic Preservation in the Twentieth-Century, Chapel Hill: University of North Carolina Press, s. 253-78.

Theunissen, K. (2010). "Flows from Early Modernism into the Interior Streets of Venturi, Rauch and Scott Brown", Architectural Research Quarterly, Sayı 14(1), s. 53-62.

UNESCO (2003). Convention for the Safeguarding of the Intangible Cultural Heritage, http://www.unesco.org/ culture/ich/en/convention (28.02.2018)

Weeks, K. D. ve Grimmer, A. D. (1995). The Secretary of Interior's Standards for the Treatment of Historic Properties: With Guidelines for Preserving, Rehabilitating, Restoring and Reconstructing Historic Buildings, Washington D.C.: U.S. Department of the Interior Park Service Cultural Resource Stewardship and Partnerships Heritage Preservation Services.

Wolfe, I. de (1949). "Townscape: A Plea for an English Visual Philosophy founded on the True Rock of Sir Uvedale Price", The Architectural Review, Sayı 106(636), s. 355-362. 